\title{
Legal protection subject of research on health research in the field of dentistry education
}

\author{
(Perlindungan Hukum Subjek Penelitian Pada Penelitian Kesehatan \\ Dalam Bidang Pendidikan Kedokteran Gigi) \\ Tahta Danifatis Sunnah; Endang Wahyati Yustina; Irma H.Y Siregar \\ email: tahtadani@gmail.com
}

Health Law Master Program, Soegijapranata Catholic University of Semarang

\begin{abstract}
Medical education is an integrated education unit of scientific knowledge and clinical science. In its implementation medical education is inseparable from researches on health as requirements of students' academic graduation in medical and dental education programs students. The researches in medical and dentistry education are carried out by the students under the academic supervisors' guidance by the field of study. The researches include observational and experimental researches. In these two types of researches, the students are required to involve the research subjects, both experimental animals and human beings. In carrying out the researches it is necessary to get the permission of the subjects to be involved as the research subjects. This relates to the rights fulfillment and legal protection of the research subjects, especially in the field of dentistry education.
\end{abstract}

This was a socio-legal study having analytically descriptive specifications. This study used primary and secondary data and the data gathering techniques were through field and literature studies. The data obtained were then qualitatively analyzed.

The results of the study showed that the legal protection, both preventive and repressive, to the health research subjects in dentistry education had not yet been realized despite there had been legal provisions regulating it, among others, Act Nr. 20 of 2013 on Medical Education and the Regulation of the Minister Research, Technology, and Higher Education of the Republic of Indonesia Nr. 18 of 2018 on National Standards of Medical Education. Also, the arrangement form of the research subject's protection in any research conducted by the students of dentistry education was a Dean Decree outlined in academic guidelines on students' scientific papers. The decree included academic, ethical, and general requirements. In practice, the existing health research legal arrangements had not been effective except in evaluation monitoring. This was because some factors influenced the legal arrangement implementation of research subjects, namely juridical factor that was the fact that the regulations were not understood by the students; a technical factor that was lack of human resources; and social factor that was lack of socialization to the health research subjects.

Keywords: health research, research subjects, legal protection, human beings, dentistry. 


\section{PENDAHULUAN}

Pendidikan kedokteran diartikan sebagai suatu pendidikan yang berisi format program pendidikan yang terintegrasi antara ilmu pengetahuan dasar dan ilmu klinik. ${ }^{1}$ Pendidikan kedokteran/kedokteran gigi pada tingkat sarjana, diterapkan proses pengembangan kinerja klinik yaitu dengan desain keterampilan klinik yang memberikan kesempatan penggunaan pengaturan kesehatan seperti kepemimpinan, infrastruktur program dan sumber daya. Hal ini dimaksudkan sebagai persiapan mahasiswa dalam partisipasi dan pembelajaran dalam menangani pasien secara langsung. ${ }^{2}$ Level pendidikan pre-klinik selain meliputi pendidikan terintegrasi tersebut juga melakukan penelitian kesehatan dibidang kedokteran (medical/health research). Hal ini sesuai dengan Peraturan Menteri Riset, Teknologi dan Pendidikan Tinggi Republik Indonesia Nomor 18 Tahun 2018 tentang Standar Nasional Pendidikan Kedokteran bagian Ketiga Belas tentang Standar Penelitian Pasal 29 ayat(2). Penelitian bidang kesehatan wajib dilakukan sebagai syarat kelulusan pendidikan kedokteran dan kedokteran gigi sebagai salah satu fasilitas dan lembaga untuk memajukan penelitian bidang kesehatan.

Diantara beberapa jenis penelitian kesehatan tentunya membutuhkan instrumen penelitian diantaranya : subjek penelitian, alat dan bahan penelitian, metode penelitian, dan lain-lain. Subjek penelitian terdiri dari makhluk hidup dan makhluk tidak hidup. ${ }^{3}$ Makhluk hidup yang dimaksud adalah hewan dan manusia. Dalam hal ini penelitian dengan hewan maupun manusia sebagai subjek penelitian dimaksudkan agar memberikan hasil penelitian yang maksimal dan akurat dalam penerapannya sehingga tidak heran dokter dan dokter gigi termasuk juga para mahasiswa kedokteran dan kedokteran gigi mencari pasien yang dapat menjadi partisipan dalam penelitian mereka, atau dengan kata lain menjadi subjek penelitian.

Dengan adanya fenomena tersebut, banyak respon dari calon subjek penelitian, sebagian dari mereka dengan senang hati menerima tawaran atau menyetujui posisinya sebagai subjek penelitian, akan tetapi kebanyakan dari mereka mengalami kesalahfahaman antara pelaku pemberi perlakuan atau dalam konteks ini adalah dokter/dokter gigi/mahasiswa kedokteran/kedokteran gigi apalagi dengan paradigma lama bahwa pasien sebagai subjek penelitian dikenal dengan istilah 'kelinci percobaan'. ${ }^{4}$ Selain itu, adanya suatu keragu-raguan dari pasien sebagai penerima perlakuan, selain itu faktor kerahasiaan yang diragukan oleh pasien akan terjaga, serta keraguan mengenai apa yang dilakukan terhadap pasien yang diduga akan membahayakan. Untuk itu pemberian informed consent sebelum dilakukannya tindakan pelayanan medis sekaligus tindakan dalam penelitian sangat diperlukan dan menjadi salah satu syarat diperbolehkannya manusia menjadi subjek penelitian.

Salah satu contoh kasus dari hal ini adalah kasus pelanggaran yang dilakukan pada penelitian diantaranya pada kasus David Reimer yang bermula pada tahun 1965, yaitu tentang statusnya sebagai pasien oleh seorang dokter jiwa yang ternyata sedang dalam penelitian mengenai pola pengasuhan yang dapat membentuk suatu karakter anak, dan bukan pembawaan alaminya. Hal ini bermula pada saat terjadi kesahalah pada prosedur sunat yang dialami David

\footnotetext{
'Djoko Susanto, 2017, Begini Mencetak Dokter Profesional, Surabaya: Airlangga University Press. hlm 21

${ }^{2}$ ibid.. hlm 14

${ }^{3}$ Kemenkes Republik Indonesia “Pedoman dan Standar Etik Penelitian dan Pengembangan Kesehatan Nasional”, https://ners.unair.ac.id/site/images/KEPK/08.\%20Pedoman\%20KEPPKN-20017.doc. Diakses pada tanggal 07/04/2019 jam 10:49wib. Hlm:58
}

${ }^{4}$ M H Pappworth. 1990. Human Guinea pigs - a history. BM Journal Volume 301. HIm:1456 
sehingga membuat alat kelaminya harus terpotong dan menyisakan sedikit bagian, dokter jiwa mereka menyarankan untuk merubah jenis kelaminnya menjadi perempuan. Eksperimen dokter jiwa tersebut berawal dari hal ini, orang tua David dipaksa untuk menyetujui tindakan tersebut dan tidak diberitahu bahwa sebetulnya yang dilakukannya adalah sebuah eksperimen mengenai tingkah laku anak tersebut, tanpa diberitahukan prosedur maupun konsekuensi. Akhir kasus ini menyebabkan David Reimer meninggal disebabkan bunuh diri karena tertekan akan jati dirinya yang menyerupai laki-laki akan tetapi menjalani hidup sebagai perempuan. ${ }^{5}$

Ilustrasi kasus tersebut menggambarkan pentingnya persetujuan dan kesediaan serta seberapa jauh penelitian kesehatan melibatkan kelangsungan hidup subjek penelitian. Selain itu, faktor lain yang mempengaruhi kesediaan pasien menjadi subjek penelitian adalah penjelasan dari dokter atau tenaga medis yang dalam hal ini juga berperan sebagai peneliti kepada pasien yang diduga ada yang disembunyikan dan tidak diungkapkan atau dalam hal ini informasi dalam informed consent yang tidak baik atau dirasa kurang. Hal ini karena dimungkinkan akan terjadi penolakan dari pasien sebagai subjek penelitian. ${ }^{6}$ Kaitannya dengan hal tersebut, pasien sebagai subjek penelitian tentunya belum memahami bahwa adanya jaminan hukum terhadap dirinya sebagai seorang subjek penelitian yang memiliki hak dan kewajiban. Selain itu, dokter/dokter gigi dan mahasiswa sebagai seorang peneliti yang dituntut untuk mengetahui hak-hak dan kewajiban mereka sebagai seorang peneliti.

Dalam suatu hubungan hukum terdapat dua jenis perikatan yaitu perikatan berdasarkan upaya (Inspanning verbitanis) dan perikatan berdasarkan hasil (resultaat verbitanis). Sementara itu hubungsn hukum antara dokter/dokter gigi dan pasien merupakan sebuah perikatan yang berdasarkan upaya atau usaha dokter/dokter gigi untuk penyembuhan pasien secara hati-hati dan cermat. ${ }^{7}$ Menurut ketentuan Pasal 1319 KUH Perdata disebutkan bahwa: "Semua persetujuan, baik yang mempunyai nama khusus maupun yang tidak dikenal dengan suatu nama tertentu, tunduk pada peraturan umum yang termuat dalam bab ini dan bab yang lain;"

Disisi lain, hubungan hukum yang terjalin antara subjek penelitian dan peneliti, yaitu dimana manusia sebagai subjek penelitian juga merupakan seorang pasien yang menerima pelayanan dan kedudukan peneliti yang juga sebagai dokter/dokter gigi yang memberikan pelayanan medis merupakan hubungan Perdata. Hal ini dijelaskan pada Pasal 1320 KUH Perdata yang didalamnya memuat ketentuan perjanjian dan persetujuan dua belah pihak tersebut dengan dua hubungan hukum yang berbeda.

Sementara itu, subjek penelitian yang telah mampu atau cakap dalam membuat perikatan dibuktikan dengan adanya pemberian informed consent, yaitu informed consent untuk tindakan medik atau lebih dikenal dengan istilah Persetujuan Tindakan Medik (PTM) dan informed consent untuk penelitian yang biasa dikenal dengan istilah Persetujuan Setelah Penjelasan (PSP). ${ }^{8}$ Tidak hanya itu, dalam kedua hubungan tersebut memiliki kesamaan yaitu pasien berhak memutuskan hubungan yang sudah terjalin baik satu maupun kedua

\footnotetext{
${ }^{5}$ Artikel. Beberapa Kasus Pelanggaran/Malpraktek Penelitian\&Publikasi. https://docplayer.info/45677851Beberapa-kasus-pelanggaran-malpraktek-penelitian-publikasi-a-kasus-1-david-reimer-lahir-di-kanada-pada-22agustus-ia-adalah-seorang-anak.html. Diakses 6 Agustus 2019. Jam 12.28. HIm1-4. ${ }^{6}$ Robert L Klitzman, 2015, The Ethics Police?: The struggle to make research safe ,Oxford University Press. hlm 273 ${ }^{7}$ M.Jusuf Hanafiah dan Amri Amir.2009. Etika Kedokteran dan Hukum Kesehatan.Ed 3 . Jakarta:EGC HIm:38-39 ${ }^{8}$ Moch.Istiadjid Edi Santoso, 2011, Buku Ajar Etik Penelitian Kesehatan. Malang :Universitas Brawijaya Pess (UB Press). hlm:45-46
} 
hubungan sekaligus, baik diawal maupun di pertengahan tindakan yang mana hal ini disebut sebagai informed refused atau suatu penolakan yang diajukan oleh pasien untuk menolak atau mengakhiri hubungan antara dokter dan pasien.$^{9}$

Hak-hak subjek penelitian beserta kewajiban peneliti meskipun secara terpisah tetapi telah dijelaskan selain dalam Undang-Undang dan beberapa peraturan tersebut di atas juga terdapat dalam KODEKI atau Kode Etik Kedokteran Indonesia. Selain itu, tindakan penelitian bidang kesehatan yang melibatkan manusia sebagai subjek hukum sebelumnya harus telah lulus dari Uji Kelaikan Etik yang diselenggarakan oleh Komisi Nasional Etik Penelitian Kesehatan (KNEPK) yang dalam suatu institusi telah di bentuk dan bernama Komite Etik Penelitian Kesehatan (KEPK). Dengan adanya KEPK tersebut memfasilitasi sekaligus menyeleksi kelayakan penelitian kesehatan termasuk Penelitian Kesehatan dengan melibatkan manusia sebagai subjek penelitian. ${ }^{10}$

Dengan adanya beberapa bentuk peraturan tersebut dokter/dokter gigi maupun mahasiswa peneliti bidang kesehatan diharapkan telah memenuhi hak-hak dari seorang subjek penelitian sehingga dapat terlindungi haknya sehingga penelitian bisa terselenggara dengan baik dan mendapatkan hasil yang menguntungkan di bidang kesehatan yang akan bermanfaat untuk masyarakat. Akan tetapi pemahaman peneliti mengenai hak-hak pasien dan hak-hak subjek penelitian kerap sekali diragukan. Dalam hal ini, adanya beberapa ketentuan mengenai perlindungan terkait perlindungan terhadap subjek penelitian kesehatan merupakan suatu upaya perlindungan secara hukum sebelum terjadinya pelanggaran terjadi atau disebut juga perlindungan hukum preventif. Hal ini ditujukan supaya menegakkan prinsip bioetik yaitu menghormati harkat dan martabat manusia (respect for persons), berbuat baik (beneficence), dan keadilan (justice). ${ }^{11}$

Berdasarkan uraian dari latar belakang tersebut peneliti tertarik untuk melakukan penelitian dan melakukan pembahasan lebih lanjut seputar penelitian kesehatan dengan manusia sebagai subjek penelitian. Adapun judul dari penelitian ini adalah "Perlindungan Hukum Subjek Penelitian pada Penelitian Kesehatan dalam Bidang Pendidikan Kedokteran Gigi" dengan pertimbangan luasnya penelitian kesehatan di bidang ini, maka pembatasan masalah dalam penelitian ini adalah penelitian kesehatan pada jenjang pendidikan akademik kedokteran gigi dengan subjek penelitian berupa manusia.

\section{PERUMUSAN MASALAH}

1. Bagaimana pengaturan tentang perlindungan hukum subjek penelitian bidang kesehatan pada pendidikan kedokteran gigi ?

2. Bagaimana pelaksanaan perlindungan hukum subjek penelitian dalam penelitian kesehatan terutama pada bidang pendidikan kedokteran gigi ?

3. Faktor-faktor apa saja yang mempengaruhi perlindungan hukum subjek penelitian bidang kesehatan pada pendidikan kedokteran gigi ?

\footnotetext{
9Kemenkes Republik Indonesia “Pedoman dan Standar Etik Penelitian dan Pengembangan Kesehatan Nasional”, https://ners.unair.ac.id/site/images/KEPK/08.\%20Pedoman\%20KEPPKN-20017.doc. Diakses pada tanggal 07/04/2019 jam 10:49wib. HIm:77

${ }^{10}$ Moch.Istiadjid Edi Santoso , op.cit.. hlm:49-50

${ }^{11}$ M.Jusuf Hanafiah dan Amri Amir.op.cit. hlm:185-186
} 


\section{METODE PENELITIAN}

1. Metode Pendekatan

Metode pendekatan yuridis sosiologis terdapat dua tinjauan penelitian yaitu melalui tinjauan yuridis atau aspek hukum dan tinjauan sosiologis atau empiris yang berdasarkan pada pengadaaan penelitian primer di lapangan, serta pembahasan mengenai aspekaspek sosial yang melingkupi gejala hukum yang membahas tentang Perlindungan Hukum Subjek Penelitian pada Penelitian Kesehatan dalam Bidang Pendidikan Kedokteran Gigi. ${ }^{12}$

\section{Spesifikasi penelitian}

spesifikasi penelitian ini termasuk penelitian diskriptif analitik.

\section{Jenis Data}

Jenis data yang dipergunakan dalam penelitian meliputi data primer dan sekunder.

a. Bahan hukum primer yaitu bahan-bahan hukum yang mengikat dalam usulan penelitian ini meliputi UUD 1945, KUH Perdata, UU, dan Permenkes. Permenristekdikti.

b. Bahan hukum sekunder

Bahan hukum sekunder yang digunakan dalam penelitian ini antara lain:

1) Kepustakaan yang berkaitan dengan penelitian ini adalah buku tentang metodologi penelitian hukum kesehatan, ilmu hukum, hubungan terapeutik, perlindungan hukum, penelitian kesehatan

2) Hasil ilmiah yang berkaitan dengan materi penelitian, berupa jurnal ilmiah, tentang perlindungan hukum subjek penelian bidang kesehatan terutama pada pendidikan kedokteran gigi.

\section{Metode pengumpulan data}

Data primer merupakan data yang diperoleh langsung dari narasumber atau langsung dari sumber pertama di lapangan melalui penelitian. Metode pengumpulan data dalam penelitian ini meliputi:

a. Studi Lapangan (Field research) yaitu dengan mengadakan wawancara kepada narasumber yaitu:

1) Ketua Komite Etik Penelitian Kesehatan Fakultas Kedokteran Gigi Universitas Islam Sultan Agung (UNISSULA), Sekretaris Komite Etik Penelitian Kesehatan Fakultas Kedokteran Gigi Universitas Muhammadiyah Semarang (UNIMUS) (Bidang Kedokteran Gigi), dan anggota Komite Etik Penelitian Kesehatan Fakultas Kedokteran Gigi Universitas Diponegoro (UNDIP) (Bidang Kedokteran Gigi) yang diwakili oleh Ketua Program Studi PSKG FK UNDIP.

2) Ketua Program Studi jenjang Akademik FKG UNISSULA, FKG UNIMUS, dan PSKG UNDIP.

3) Perwakilan Dosen Pembimbing Penelitian Mahasiswa FKG UNISSULA, FKG UNIMUS, dan PSKG UNDIP.

Dan wawancara kepada informan yaitu :

1) Mahasiswa Kedokteran Gigi yang melakukan penelitian dengan manusia sebagai subjek penelitian dari FKG UNISSULA, FKG UNIMUS (masing-masing sebanyak 5 mahasiswa) dan PSKG UNDIP ( sebanyak 1 mahasiswa)

\footnotetext{
${ }^{12}$ Soerjono Soekanto, 1986, Pengantar Penelitian Hukum, Jakarta : Universitas Indonesia Press, hlm:52
} 
2) Subjek penelitian atau manusia yang menerima intervensi atau suatu tindakan dalam penelitian oleh mahasiswa Kedokteran Gigi FKG UNISSULA dan FKG UNIMUS (masing-masing sebanyak 5 mahasiswa)

b. Studi Kepustakaan (Library research) yaitu dengan membaca, mempelajari dan menganalisa buku-buku yang berhubungan dengan tanggung jawab tukang gigi dalam pelaksanaan pekerjaan berisiko terhadap konsumen sebagai data sekunder.

\section{Definisi operasional}

a. Perlindungan hukum subjek penelitian : perlindungan terhadap hak-hak yang dimiliki oleh manusia yang berperan dalam penelitian sebagai penerima intervensi yang dilakukan oleh peneliti. ${ }^{13}$

b. Penelitian bidang kesehatan : penelitian yang memiliki input, metode, dan output baik berupa ilmu pengetahuan maupun penemuan ilmiah dibidang kesehatan. ${ }^{14}$

c. Subjek penelitian : adalah setiap orang atau manusia yang dalam hubungannya dengan penelitian merupakan subjek penerima intervensi dalam penelitian. ${ }^{15}$ Dalam hal ini subjek penelitian dihubungkan dengan perannya sebagai pasien yang menerima layanan atau perlakuan medis.

d. Peneliti : adalah seorang pelaksana dan pengelola program untuk memecahkan masalah yang akan diteliti dalam sebuah penelitian. ${ }^{16}$ Dalam konteksi ini peneliti dihubungkan dengan peran dokter sebagai seorang pemberi layanan atau perlakuan medis.

\section{Teknik pengumpulan sampel}

Teknik pengambilan sampel dalam penelitian ini adalah Non Random Sampling dengan teknik purposive sampling. ${ }^{17}$

\section{Teknik analisis}

Penyajian data akan disusun secara sistematis dalam bentuk teks yang sistematis, berupa uraian kalimat-kalimat yang dilengkapi dengan gambar, dan penyajian data dalam bentuk tabel hasil penelitian. Analisa data dalam penelitian ini dilakukan secara kualitatif, yaitu dengan menentukan isi atau makna suatu aturan hukum yang dijadikan rujukan dalam menyelesaikan permasalahan hukum yang menjadi objek kajian.

\section{PEMBAHASAN}

Penelitian dilakukan di tiga program studi kedokteran gigi yang bertempat di Kota Semarang, yaitu Program Studi Kedokteran Gigi UNISSULA, UNIMUS, dan UNDIP. Pada ketiga program studi yang dilakukan penelitian tentang Perlindungan Hukum Subjek Penelitian pada Penelitian Kesehatan dalam Bidang Pendidikan Kedokteran Gigi melalui wawancara dengan narasumber dari pihak KEPK, Ketua program studi, dan perwakilan Dosen Pembimbing Akademik dari masing-masing institusi pendidikan kedokteran gigi dan wawancara informan

\footnotetext{
${ }^{13}$ Rianto Adi, 2005, Metodologi Penelitian Sosial dan Hukum, Jakarta : Granit, hlm. 104

${ }^{14}$ Trevor smith. 2001. Ethics in Medical Research: A Handbook of Good Practice. Newyork: Cambridge University Press. Hlm: 11

${ }^{15}$ Muh. Fitrah dan Lutfiyah, 2017. Metodologi Penelitian: Penelitian Kualitatif, Tindakan Kelas\&Studi Kasus. Sukabumi:CVJejak. hlm:153

${ }^{16}$ Eko Budiarto. 2003. Metodologi Penelitian Kedokteran: Sebuah Pengantar.Jakarta:EGC. hlm:214

${ }^{17}$ M.Burhan Bungin.2017. Metodologi Penelitian Kuantitatif. Komunikasi,Ekonomi,dan Kebijakan Publik Serta Ilmu-ilmu sosial Lainnya. Jakarta:PT Fajar Interpratama Mandiri.Hlm: 126
} 
yaitu sebelas mahasiswa yang melakukan penilitian dengan melibatkan manusia, dan sepuluh manusia sebagai subjek penelitian.

1. Pengaturan tentang Perlindungan Hukum Subjek Penelitian Kesehatan pada Bidang Pendidikan Kedokteran Gigi

a. Bentuk Pengaturan

1) Instrumen Hukum Umum

Pengaturan mengenai penelitian kesehatan pada institusi pendidikan kedokteran/kedokteran gigi di atur dalam beberapa instrumen hukum yang dipergunakan sebagai landasan dalam pelaksanaan penelitian kesehatan. Instrumen hukum tersebut tertuang pada berbagai peraturan perundangundangan, yang dapat dijelaskan sebagai berikut

\section{a) Kitab Undang-Undang Hukum Perdata}

Pasal 1319 yang menerangkan bahwa hubungan yang terjadi antara peneliti yang dalam hal ini dilaksanakan oleh mahasiswa dengan subjek penelitian yaitu manusia merupakan sebuah hubungan hukum perdata.

b) Undang-Undang Republik Indonesia No.36 Tahun 2009 tentang Kesehatan Pada Bagian Keempat, Teknologi dan Produk Teknologi, Pasal 42 menerangkan bahwa dengan adanya pasal ini yang sekaligus melengkapi pasal sebelumnya, semakin jelas bahwa perijinan dalam pembuatan ataupun pemanfaatan teknologi dan produk teknologi kesehatan harus aman jika dilakukan terhadap manusia.

c) Peraturan Kepala Lembaga Ilmu Pengetahuan Indonesia Nomor 06/E//2013 Tentang Kode Etik Peneliti Bab II Kode Etik Peneliti:

(1) Dalam Bagian 2.1 Kode Etika dalam Penelitian 2.1.1 hingga 2.1.3

Berdasarkan ketentuan tersebut dijelaskan beberapa sikap ilmiah yang diharapkan harus ada pada setiap individu yang melakukan penelitan sehingga dapat mendapatkan hasil penelitian yang baik, tanggung jawab dan cara enyampaian ilmiah yang sesuai

(2) Dalam Bagian 2.2 Kode Etika dalam Berperilaku 2.2.1 hingga 2.2.3

Berdasarkan ketentuan tersebut dijelaskan menegaskan bahwa perlakuan peneliti terhadap subjek penelitian yang berupa manusia ataupun bukan manusia harus didasari sikap dasar berbuat baik tanpa diskriminasi peneliti juga harus terbuka dalam menerima kritik dan saran yang menyangkut penelitiannya sehingga dapat menghasilkan hasil penelitian yang informatif dan bersifat objektif dan ilmiah

(3) Dalam Bagian 2.3 Kode Etika dalam Kepengarangan 2.3.1 hingga 2.3.3

Dalam hal kepengarangan, disebutkan dalam bagian ini, pneliti harus bersikap jujur dan cermat sehingga hasil penelitian juga dapat secara relevan dipertanggungjawabkan dan dipergunakan sebagai acuan penelitan mendatang. Peneliti juga dituntut untuk teliti dalam publikasi, hal ini disebabkan publikasi ganda tidak diperkenankan dalam sebuah penelitian, sehingga peneliti perlu waspada dalam hal kepengarangan, khususnya dalam tata cara publikasi. 
2) Instrumen Hukum Khusus:

a) Undang- Undang Republik Indonesia No.24 Tahun 2004 tentang Praktik Kedokteran

Paragraf 7 Tentang Hak dan Kewajiban Pasien Pasal 52 di dalamnya dijelaskan kaitan penelitian kesehatan dengan Undang-Undang praktik kedokteran adalah dikarenakan adanya hubungan antara peneliti dan subjek penelitian yang menerima tindakan oleh mahasiswa kedokteran/kedokteran gigi yang mana sama halnya dengan pada saat pelaksanaan praktik kedokteran/kedokteran gigi yang dilaksanakan dengan pemberian informed consent terlebih dahulu oleh pasien maupun subjek penelitian kesehatan yang mana pasien juga memeiliki hak untuk menerima ataupun menolak tindakan yang akan dilakukan kepada dirinya.

b) Undang-Undang No.20 Tahun 2013 Tentang Pendidikan Kedokteran

Bagian Kesepuluh Mahasiswa, Paragraf 3 Hak dan Kewajiban Mahasiswa Pasal 31 Ayat (2), Kemudian dilanjutkan dengan Bagian Keempatbelas Penelitian, Pasal 46. Dengan adanya ketentuan tersebut dapat diketahui bahwa sebagai mahasiswa kedokteran/kedokteran gigi berkewajiban melaksanakan penelitian kesehatan sebagai suatu syarat mencapai kelulusan dan dalam hal ini dalam pelaksanaan penelitian yang sesuai dengan peraturan perundanga-undangan bahwa dalam pelaksanaannya yang melibatkan hewan atau manusia harus disertai dengan kelolosan kaji etik yang dilakukan oleh KEPK suatu institusi dengan kelolosan semua aspek/standart berdasar kepada WHO 2011 dalam telaah laik etik, yaitu :

a) Nilai Sosial (Social Values)

b) Nilai Ilmiah (Scientific Values)

c) Pemerataan Beban dan Manfaat (Equitable Assessement and Benefit)

d) Risiko (Risks)

e) Bujukan / Eksploitasi (Persuasion/ Eksploitation)

f) Kerahasisiaan dan Privacy (Confidentially and Privacy)

g) Persetujuan Setelah Penjelasan (Informed Consent)

c) Peraturan Menteri Riset, Teknologi, Dan Pendidikan Tinggi Republik Indonesia Nomor 18 Tahun 2018 tentang Standar Nasional Pendidikan Kedokteran

Bagian Ketiga Belas Standar Penelitian Pasal 29

Dalam pasal tersebut penelitian pada tingkat akademik yang merupakan salah satu persyaratan kelulusan jenjang akademik dilaksanakan oleh mahasiswa didasarkan pada Undang-Undang yang berlaku serta diharuskan dalam pelaksanaannya di lakukan dibawah arahan dan bimbingan dosen.

d) Peraturan Internal Institusi

Instrumen hukum dalam pelaksanaan penelitian kesehatan yang dilakukan oleh mahasiswa kedokteran gigi di sebuah institusi pendidikan dituangkan dalam bentuk buku pedoman pelaksanaan/penulisan Karya Tulis Ilmiah yang disusun oleh Fakultas maupun program studi yang dipakai sebagai panduan mahasiswa dalam menulis Karya Tulis Ilmiah. 
(1) FKG UNISSULA

Peraturan internal Fakultas Kedokteran Gigi UNISSULA yang tertuang pada buku pedoman penulisan Karya Tulis Ilmiah (KTI) mahasiswa, sementara itu dalam pengajuan usulan judul KTI mahasiswa dapat mengakses melalui situs web dan form akan diisi dan di submit sehingga dapat diproses secara online untuk dilakukan penentuan pembimbing yang sesuai dengan kompetensi bidang terkait.

(2) FKG UNIMUS

Peraturan internal institusi pendidikan Fakultas Kedokteran Gigi UNIMUS juga menyantumkan beberapa aturan terkait pedoman pelaksanaan penelitian mahasiswa dalam bentuk manual book penulisan Karya Tulis Ilmiah (KTI) mahasiswa. Dalam pengajuan judul, pengajuan Ethical Clearance (EC), pengajuan menguji, permohonan penggunaan laboratorium dan lain-lain terdapat ketentuan pengisian form yang bisa diakses melaui website http://fkg.unimus.ac.id kemudian dilakukan pemetaan dan pembagian dosen pembimbing oleh bagian penelitian FKG UNIMUS.

\section{(3)FKG UNDIP}

Peraturan Internal mengenai pedoman penulisan Karya Tulis IImiah (KTI) mahasiswa pada Program Studi Kedokteran Gigi FK UNDIP dituangkan dalam sebuah buku ajar penulisan Karya Tulis Ilmiah yang disusun oleh Fakultas Kedokteran (FK) UNDIP hal ini dikarenakan PSKG UNDIP masuk dalam satu Fakultas yaitu Fakultas Kedoteran. Peraturan mengenai alur beserta penjelasannya dijelaskan dalam buku ajar tersebut.

Berdasarkan ketentuan masing-masing program studi yang menjadi objek penelitian, diketahui bahwa prosedur penelitian yang tertuang dalam peraturan akademik pada ketiga objek penelitian adalah sama. Hal ini dapat dijabarkan sebagai berikut:

(1) Pengajuan penelitian: pengajuan judul proposal yang diajukan melalui website program studi. Kemudian pengajuan akan diproses oleh bagian akademik dan akan disesuaikan dengan kompetensi dosen yang bersangkutan, setelahnya akan dilakukan pembagian dosen pembimbing. Mahasiswa akan secara langsung melakukan proses pembimbingan dengan DPA sesuai dengan pembagian dengan draft proposal yang akan diusulkan melalui prosedur sidang proposal Karya Tulis Ilmiah mahasiswa.

(2) Proses penelitian: Setelah proposal disetujui dalam sidang proposal maka akan dilanjutkan dengan proses pengurusan persyaratan, baik secara akademik, etik, dan persyaratan umum lainnya. Penelitian mahasiswa akan berjalan jika ketiga persyaratan ini telah diselesaikan.

(3) Pelaporan Hasil penelitian Setelah dilakukannya penelitian, tahap selanjutnya adalah pelaporan hasil dengan sebelumnya dilakukan pembimbingan dari DPA kepada mahasiswa. Setelah hasil tersusun, maka akan diseminarkan pada seminar hasil penelitian. Dalam proses bimbingan mulai dari awal hingga setelah penelitian, mahasiswa wajib untuk menyertakan buku bimbingan dan konseling dalam penyusunan Karya Tulis IImiah. 
b. Tujuan Pengaturan terhadap Penelitian Kesehatan yang dilakukan oleh Mahasiswa Berdasarkan Paraturan Menteri Riset dan Teknologi dan Pendidikan Tinggi Republik Indonesia Nomor 18 Tahun 2018 Tentang Standar Nasional Pendidikan Kedokteran, tujuan pengaturan pelaksanaan penelitian kesehatan ini sebagai pelaksanaan dari ketentuan Pasal 24 ayat (2) Undang-Undang Nomor 20 Tahun 2013 tentang Pendidikan Kedokteran. Tujuan dilakukannya pengaturan terhadap penelitian kesehatan yang dilakukan Pengaturan tentang penelitian kesehatan oleh mahasiswa adalah:

1) Sebagai suatu upaya penjaminan mutu dalam hal pendidikan, penelitian, dan pengabdian kepada masyarakat yang diselenggarakan oleh fakultas kedokteran dan kedokteran gigi yang sesuai dengan kriteria yang telah ditetapkan dalam Standar Nasional Pendidikan Kedokteran

2) Mendorong pencapaian mutu pendidikan dan penelitian serta pengabdian masyarakat yang dilakukan oleh fakultas kedokteran dan kedokteran gigi melampaui kriteria yang ditetapkan oleh Standar Nasional Pendidikan Kedokteran secara berkelanjutan.

Dalam hal ini pelaksanaan penelitian kesehatan yang dilakukan oleh mahasiswa adalah sebuah penelitian kesehatan sebagai sebuah legalitas dan persyaratan akademik dalam penyelenggaraan pendidikan kedokteran gigi, dan bukan merupakan penelitian umum populer.

Tujuan pengaturan hukum termasuk terhadap subjek penelitian pada penelitian kesehatan yang dilakukan oleh Mahasiswa juga untuk memenuhi hak-hak pasien secara umum. Hal ini juga sesuai dengan tulisan dari Endang Wahyati Yustina, 2018 dalam jurnalnya yang berjudul Withdrawing Life Supports Theraphy in Human Rights Perspective bahwa

"Thus, human rights can be regarded as a basic right possessed by the human being as a God-given gift born. Human rights cannot be separated from the existence of the human being itself"

Selanjutnya dalam jurnal yang sama disebutkan juga bahwa:

"The right to a healthy life is a fundamental right to be guaranteed because health is part of every human's primary needs. A healthy condition of body and soul will enable every human being to perform his activities and his work. Health is also part of the need for prosperity. This right is to be one of the basic rights of health care. In addition, everyone is guaranteed to determine his health needs in accordance with his choice (the right of self determination)"

Hal ini menjelaskan bahwa satu hal yang penting dalam hak-hak manusia adalah kebebasan manusia dalam menentukan pilihan dan hak privasi manusia itu sendiri. Hak dalam kesehatan ini bagi setiap individu merupakan hal yang sangat mendasar untuk dijamin keberlangsungannya, hal ini dikarenakan kesehatan merupakan kebutuhan utama setiap manusia. Dalam hal ini membuktikan bahwa terdapat keterkaitan antara kesehatan dan hak-hak manusia sebagai pasien salah satunya adalah kesehatan seseorang bisa saja merupakan cerminan atau refleksi dari terpenuhinya hak-hak manusia tersebut. pemenuhan kebutuhan dalam hal kesehatan masyarakat ini tentunya di sesuaikan dengan prinsip-prinsip pemenuhan hak-hak manusia sebagai warga negara. ${ }^{18}$

\footnotetext{
${ }^{18}$ Endang Wahyati Yustina, 2018. "Withdrawing life supports theraphy in human rights perspective". Journal of Advances in Heath and Medical Science. Vol: 4(2):32-42. hlm: 34-36
} 
Tujuan lain mengenai perlindungan hukum pasien sebagai subjek penelitian yang serupa berkaitan dengan hak individu dalam pemenuhan kebutuhan pelayanan kesehatan juga terdapat dalam ruang lingkup Hak Asasi Manusia (HAM) dimana dalam jurnal yang ditulis oleh Endang Wahyati Yustina, 2014 tentang Hak atas Informasi Publik dan Hak atas Rahasia Medis: Problem Hak Asasi Manusia dalam pelayanan Kesehatan dikemukakan bahwa: ${ }^{19}$

"Dalam ruang lingkup HAM terdapat dua hak yang seringkali berbenturan padahal kedudukannya sama penting dan keduanya harus dijamin perlindungannya. Hak atas informasi kesehatan dalam ruang lingkup (public) yang utama adalah hak akses terhadap pelayanan kesehatan. Sementara hak menentukan diri sendiri diturunkan dalam beberapa hak antara lain ha katas rahasia medis merupakan hak individu yang juga harus dilindungi. “

\section{Pelaksanaan Perlindungan Hukum Subjek Penelitian dalam Penelitian Kesehatan pada Bidang Pendidikan Kedokteran Gigi}

Penelitian kesehatan merupakan salah satu kegiatan dalam kurikulum pendidikan akademik meliputi pelaksanaan penelitian mahasiswa. Dalam hal ini, pihak institusi dengan berdasar kepada Pedoman Nasional Penelitian Kesehatan oleh mahasiswa yang telah disesuaikan dengan kurikulum pendidikan kedokteran gigi menerapkan beberapa persyaratan dan mekanisme, serta prosedur monitoring dan evaluasi pelaksanaan penelitian kesehatan yang dilakukan oleh mahasiswa.

\section{a. Persyaratan dalam pelaksanaan penelitian kesehatan oleh mahasiswa}

1) Persyaratan Akademik

Persyaratan akademik dalam penyelenggaraan penelitian kesehatan dilakukan oleh mahasiswa harus sesuai dengan ketentuan institusi masing-masing. Hal ini berkaitan dengan kemampuan mahasiswa menyelesaikan beban modul atau SKS dan melalui tahap ujian proposal pengajuan penelitian kesehatan yang dilanjutkan dengan proses pembimbingan dengan Dosen Pembimbing Akademik (DPA). Hal ini telah disebutkan pada buku pedoman penulisan Karya Tulis Mahasiswa (KTI) yang didasarkan pada Surat Keputusan Dekan Fakultas.

Berdasarkan hasil wawancara dan observasi, semua mahasiswa telah melaksanakan masing-masing alur tersebut dengan baik. Hal ini dimulai dari penyelesaian beban SKS dan kelulusan modul metodologi penelitian di FKG UNISSULA dan PSKG UNDIP, dan modul biostatistika penelitian di FKG UNIMUS yang kemudian dilanjutkan dengan pengajuan judul penelitian sesuai dengan alur masing-masing institusi.

2) Persyaratan Etik

Persyaratan Etik sebagai salah satu syarat dilangsungkannya penelitian kesehatan mahasiswa pada ketiga institusi pendidikan kedokteran gigi yaitu FKG UNISSULA, FKG UNIMUS, dan PSKG FK UNDIP pada dasarnya sama. Persyaratan etik yang diterapkan oleh ketiga insitusi tersebut sesuai dengan peraturan nasional dalam pelaksanaan penelitian kesehatan yang tertuang dalam Undang- Undang Republik Indonesia No.24 Tahun 2004 tentang Praktik Kedokteran, Undang-Undang No. 20

${ }^{19}$ Endang Wahyati Yustina, 2014. "Hak atas Informasi Publik dan Hak atas Rahasia Medis: Problem Hak Asasi Manusia dalam pelayanan Kesehatan”. Padjajaran Jurnal Ilmu Hukum, Volume 1(2). Hlm:264-266 
Tahun 2013 Tentang Pendidikan Kedokteran, Peraturan Menteri Riset, Teknologi, Dan Pendidikan Tinggi Republik Indonesia Nomor 18 Tahun 2018 Tentang Standar Nasional Pendidikan Kedokteran.

Berdasarkan hasil penelitian, prosedur pengusulan hingga persetujuan laik etik di ketiga institusi pada dasarnya sama, yaitu ditujukan dan dilakukan oleh KEPK pada institusi terkait, yang berbada adalah pada FKG UNISSULA, KEPK berdiri secara mandiri di FKG UNISSULA, sementara FKG UNIMUS dan PSKG FK UNDIP, KEPK berdiri secara mandiri pula pada Fakultas Kedokteran (FK) sehingga pada pengurusannya akan dialihkan pada KEPK FK UNIMUS, dan KEPK FK UNDIP. yang nantinya akan dilakukan prosedur telaah laik etik oleh KEPK sutatu institusi yang dipilih untuk menerbitkan Ethical Clearance (EC) yang merupakan persyaratan etik pelaksanaan penelitian kesehatan. Dalam pengajuan EC akan disertakan surat ijin penelitian yang diberikan oleh institusi terkait dan pengisian form laik etik secara online dan selanjutnya dilakukan telaah dan review oleh tim KEPK. Apabila ada yang belum terpenuhi akan di informasikan untuk dilakukan revisi oleh mahasiswa yang bersangkutan kemudian proses review akan dilanjutkan dan diakhiri dengan penandatanganan EC oleh ketua KEPK.

Dalam pelaksanaannya, beberapa mahasiswa masih ada yang melaksanakan penelitian meskipun Ethical Clearance (EC) belum diterbitkan. Tindakan ini tidak sesuai dengan peraturan mengenai penelitian kesehatan termasuk penelitian mahasiswa kedokteran/kedokteran gigi. Sehingga hal ini bisa berdampak pada pelanggaran hukum. Hal semacam inilah yang masih belum dipahami oleh mahasiswa bahwa pelanggaran yang dianggap tidak berarti dapat berdampak terjadinya pelanggaran hukum.

3) Persyaratan Umum

Selain kedua persyaratan di atas, persyaratan umum lain yaitu surat rekomendasi dari institusi juga dibutuhkan. Surat ijin penelitian yang dikeluarkan oleh institusi akan berguna sebagai suatu sarana perijinan dari institusi pendidikan kedokteran gigi yang diberikan kepada institusi tujuan penelitian. Selain itu surat ini juga berguna dalampembuatan Ethical Clearance (EC) atau uji laik etik seperti yang dijelaskan diatas.

Berdasarkan hasil observasi dan wawancara yang telah dilakukan, dalam hal pengurusan ijin penelitian pada semua program studi kedokteran gigi akan memfasilitasi perijinan penelitian, dimana hal ini meliputi surat pengantar dari institusi untuk tempat tujuan tertentu ataupun perorangan sebagai subjek penelitian atau perwakilannya.

\section{b. Mekanisme Pelaksanaan Penelitian Kesehatan oleh Mahasiswa}

Berdasarkan Peraturan Menteri Riset, Teknologi, dan Pendidikan Tinggi Republik Indonesia Nomor 18 Tahun 2018 tentang Standar Nasional Pendidikan Kedokteran dalam pelaksanaan proses penelitian kesehatan yang dilakukan oleh mahasiswa kedokteran gigi, dilakukan dengan pendampingan oleh Dosen Pembimbing Akademik (DPA) sesuai dengan peran dan kompetensi masing-masing Dosen Pembimbing Akademik (DPA) yang telah disesuaikan dengan materi yang relevan dengan penelitian yang dilakukan oleh mahasiswa. 
Persiapan terhadap segala persyaratan termasuk informed consent harus dipenuhi oleh mahasiswa. Selain itu, penjelasan mengenai tujuan, prosedur dan resiko yang tertuang dalam informed consent harus diutarakan oleh peneliti karena hal ini merupakan satusatunya bukti kesediaan keterlibatan manusia sebagai subjek penelitian yang diberikan oleh subjek penelitian tersebut.

Berdasarkan hasil penelitan berupa observasi dan wawancara langsung tentang mekanisme pelaksanaan penelitian oleh mahasiswa masih belum terlaksana optimal, antara lain:

1) Dalam penelitian yang melibatkan subjek rentan, sebagai contoh anak-anak, informasi tentang tujuan, prosedur dan risiko belum dapat dimengerti oleh orang tua siswa dengan baik, dikarenakan persetujuan telah diwakilkan langsung secara menyeluruh dengan guru pendamping. Sehingga apabila ada pertanyaan dari orang tua belum bisa tersampaikan dan terjawab langsung oleh peneliti.

2) Subjek penelitian yang merupakan junior dari peneliti (mahasiswa kedokteran gigi) masih kurang puas mengenai keterangan dari penyampaian tujuan, prosedur, dan risiko yang banyak diabaikan oleh peneliti.

Berdasarkan dua hal tersebut, diketahui bahwa pelaksanaan penelitian mahasiswa program studi kedokteran gigi beberapa diantaranya masih bersifat subjektif. Hal ini menyebabkan hasil penelitian menjadi subjektif sehingga hasil penelitian juga masih kurang dijamin objektifitasnya.

\section{c. Monitoring dan evaluasi}

Monitoring dilakukan oleh pihak akademik dengan pemantauan pelaksanaan penelitian yang dilakukan oleh mahasiswa. Disisi lain, KEPK menyarankan pelaksanaan monitoring untuk memastikan tidak adanya terjadinya pelanggaran yang dimungkinkan, dimana hal ini biasanya terjadi bukan pada saat pengajuan laik etik yang menyalahi protokol etik atau standar, akan tetapi dari segi pelaksanaan yang kurang memenuhi prinsip kemanusiaan, sebagai contoh tidak adanya pemberian kompensasi penelitian dari peneliti.

Berdasarkan hasil penelitian, evaluasi dilaksanakan dimulai dari adanya bimbingan dan konseling mahasiswa pada Dosen Pembimbing Akademik (DPA) dengan menyertakan buku bimbingan yang di lengkapi oleh DPA. Dimana dalam buku bimbingan ini berisi setiap tahapan dan progress mahasiswa dalam melaksanakan penelitian dan pelaporan hasil penelitian. Monitoring dan evaluasi selesai hingga dilangsungkannya ujian hasil penelitian yang dilampirkan dokumentasi dan dipaparkan hasil penelitian termasuk kendala maupun kritik dan saran penelitian. Selain itu, pendampingan dari DPA juga meliputi pelaksanaan trial awal penelitian, pembimbingan pra-penelitian, mahasiswa akan mendapatkan pendampingan lapangan apabila dibutuhkan atau diajukan sendiri oleh mahasiswa terkait. Yaitu dengan membuat surat penhgajuan penelitian kepada DPA yang disetujui oleh kaprodi.

\section{d. Bentuk Perlindungan hukum Subjek Penelitian Kesehatan dalam Bidang Pendidikan Kedokteran Gigi}

Perlindungan hukum terhadap subjek penelitian kesehatan dalam pendidikan kedokteran gigi meliputi dua bentuk perlindungan hukum, yaitu: 


\section{1) Perlindungan Hukum Preventif}

Upaya perlindungan hukum preventif adalah suatu upaya hukum dalam hal pencegahan untuk mengurangi kemungkinan hal-hal ynag tidak diinginkan disutu masa mendatang. Bentuk perlindungan preventif semacam ini dalam kaitannya dengan penelitian kesehatan yang dilakukan oleh mahasiswa dalam jenjang akademik dituangkan dalam bentuk peraturan-peraturan yang diterapkan sebelum, pada saat dan setelah melaksanakan penelitian kesehatan.

Berdasarkan hasil penelitian, salah satu upaya perlindungan hukum preventif untuk subjek penelitian yang telah diberlakukan oleh institusi yaitu dengan menerapkan beberapa persyaratan-persyaratan yang meliputi persyaratan akademik, persyaratan etik, dan persyaratan umum lainnya. Ketiga persyaratan ini secara garis besar sudah terlaksana, akan tetapi persyaratan umum yang meliputi persetujuan dalam informed consent yang belum semua diverbalkan kemudian di tandatangani, kebanyakan subjek penelitian hanya mengetahui sepintas tetapi tetap bersedia menandatangani meskipun belum keseluruhan isinya dipahami.

Disisi lain, institusi terkait juga terikat dengan peraturan dalam pembuatan kebijakan dalam pelaksanaan penelitian tersebut memiliki kewajiban untuk mematuhi peraturan perundang-undangan yang berlaku. Hal ini merupakan salah satu upaya perlindungan hukum preventif terhadap peneliti. Dengan dipatuhinya semua peraturan perundangan-undangan terkait, maka kemungkinan kecil mahasiswa akan melakukan pelanggaran dalam penelitian, secara garis besar mahasiswa telah melaksanakan ketentuan tersebut, akan tetapi tanpa pemahaman yang baik, hal ini terbukti dengan persyaratan internal institusi yang masih sering disepelekan yaitu pemberian penjelasan dalam informed consent yang belum maksimal.

\section{2) Perlindungan Hukum Represif}

Sementara itu, perlindungan hukum represif merupakan sebuah upaya perlindungan hukum yang berupa tindakan pengendalian sosial terhadap suatu yang telah dilakukan pelanggaran dan menimbulkan sengketa.

Berdasarkan hasil penelitian, perlindungan hukum represif dilakukan dengan adanya monitoring dan evaluasi terhadap mahasiswa dengan cara pelaporan maupun pendampingan oleh DPA. Selanjutnya buku bimbingan dalam monitoring tersebut sekaligus sebagai evaluasi mahasiswa terhadap poin-poin yang perlu diperbaiki dalam perbaikan penulisan hasil penelitian. Hal ini telah dilaksanakan oleh seluruh mahasiswa. selain itu, mekanisme pengaduan atau komplain baik secara langsung maupun secara tidak langsung melalui instansu atau peneliti. Pemberian sanksi maupun mahasiswa kembali melakukan pencarian subjek peneliti pada populasi yang lain dalam pelaksanaan pengulangan penelitian yang hingga saat ini belum pernah terjadi pada ketiga institusi pendidikan kedokteran gigi yang dilakukan observasi. 
3. Faktor-faktor yang mempengaruhi Perlindungan Hukum Subjek Penelitian Bidang Kesehatan pada Pendidikan Kedokteran Gigi

Berdasarkan hasil penelitian diketahui perlindungan hukum subjek penelitian dalam penelitian kesehatan dalam pendidikan kedokteran gigi masih belum sepenuhnya diberikan secara optimal. Faktor-faktor yang mempengaruhi pelaksanaan perlindungan hukum subjek penelitian pada penelitian bidang kedokteran gigi tersebut adalah:

\section{a. Faktor Yuridis}

Pelaksanaan perlindungan hukum subjek penelitian pada penelitian kesehatan dalam pendidikan kedokteran gigi, secara yuridis mengacu pada Undang-Undang Republik Indonesia Nomor 20 Tahun 2013 Tentang Pendidikan Kedokteran.. Selain itu, Peraturan Menteri Riset, Teknologi dan Pendidikan Tinggi Nomor 18 Tahun 2018 Tentang Standar Nasional Pendidikan Tinggi yang telah menerangkan ketentuan-ketentuan penelitian kesehatan yang dilakukan oleh mahasiswa, akan tetapi sangat minim dipahami oleh mahasiswa. terutama dari segi penerapannya.

Peraturan yang telah ada tersebut belum sepenuhnya terlaksana maksimal, dikarenakan beberapa faktor yaitu:

1) Penegakan peraturan yang kurang maksimal

2) Adanya konskuensi dan sanksi dari peraturan yang belum dipahami

3) Peraturan internal yang belum lengkap

\section{b. Faktor Teknis}

Dalam pelaksanaan perlindungan hukum subjek penelitian dalam penelitian kesehatan dalam pendidikan kedokteran gigi, secara teknis dipengaruhi oleh beberapa faktor teknis diantaranya adalah:

1) Rasio Dosen dan Mahasiswa yang kurang memadai

2) Lemahnya pelaksanaan monitoring dan evaluasi

\section{c. Faktor Sosial}

Dalam pelaksanaan perlindungan hukum subjek penelitian dalam penelitian kesehatan dalam pendidikan kedokteran gigi, secara teknis terdiri dari dua aspek umum yaitu aspek peneliti dan aspek subjek peneliti, dimana keduanya dipengaruhi oleh:

1) Kurangnya pemahaman subjek penelitian terhadap hukum yang berlaku

2) Kurangnya komunikasi dalam pelaksanaan penelitian kesehatan

\section{KESIMPULAN}

a. Pengaturan tentang perlindungan hukum subjek penelitian kesehatan bidang pendidikan kedokteran gigi dalam beberapa instrumen hukum ini baik umum maupun khusus, belum dapat mengakomodasi seluruh pelaksanaan penelitian kesehatan yang dilakukan oleh mahasiswa hal ini dikarenakan beberapa peraturan tersebut kurang dimengerti kedudukannya oleh mahasiswa, diantaranya setiap pelanggaran atau pelaksanaan peraturan yang kurang sesuai dapat memiliki konskuensi hukum.

b. Pelaksanaan Perlindungan Hukum Subjek Penelitian Kesehatan Bidang Pendidikan Kedokteran Gigi

1) Persyaratan pelaksanaan hukum subjek penelitian kesehatan bidang pendidikan kedokteran gigi terdiri dari persyaratan akademis, persyaratan etik dan persyaratan umum berupa beberapa perijinan terkait pelaksanaan penelitian. 
Semua persyaratan ini dalam pelaksanaannya masih belum sesuai dengan peraturan yang berlaku, hal ini terbukti dengan beberapa mahasiswa yang masih melaksanakan penelitian sebelum Ethical Clearance (EC) selesai diterbitkan.

2) Mekanisme pelaksanaan perlindungan hukum subjek penelitian kesehatan bidang pendidikan kedokteran gigi belum sesuai dengan ketentuan yang berlaku, terbukti ketika mahasiswa melaksanakan penelitian dengan subjek penelitian dengan junior (mahasiswa kedokteran gigi) informasi mengenai tujuan, prosedur dan risiko belum disampaikan dengan baik.

3) Monitoring dan evaluasi. Dalam hal ini, pelaksanaan monitoring dan evaluasi sudah efektif dilakukan terhadap mahasiswa yang didukung oleh peran DPA.

4) Perlindungan hukum preventif dan represif terhadap subjek penelitian kesehatan bidang pendidikan kedokteran gigi belum dapat tercapai dengan optimal.

c. Faktor-faktor yang mempengaruhi perlindungan hukum subjek penelitian kesehatan bidang pendidikan kedokteran gigi dipengaruhi oleh beberapa faktor yaitu

1) faktor yuridis, hal ini dikarenakan peraturan yang belum dipahami, sanksi pelanggaran yang belum diberikan, dan sosialisasi terhadap peraturan ynag belum dijalankan secara efektif.

2) faktor teknis, diantaranya adalah kurang Sumber Daya Manusia (SDM) yang kurang sehingga rasio dosen dan mahasiswa juga tidak seimbang.

3) faktor sosial, yaitu berkaitan dengan keterlibatan manusia sebagai subjek penelitian, Diantaranya adalah kurangnya pemahaman subjek penelitian terhadap hukum yang berlaku dan kurangnya komunikasi dalam pelaksanaan penelitian kesehatan.

\section{SARAN}

a. Untuk Fakultas atau Program Studi Kedokteran Gigi, perlu mengadakan sosialisasi secara efektif kepada mahasiswa. Selain itu, perlu dibuat pengaturan internal institusi yang lebih spesifik mengenai penelitian mahasiswa yang melibatkan manusia sebagai subjek penelitian. Serta perlu penambahan Sumber Daya Manusia (dosen).

b. Untuk dosen pembimbing harus lebih teliti dalam pengawasan pelaksanaan penelitian kesehatan yang dilakukan oleh mahasiswa.

c. Untuk Mahasiswa perlu memahami peraturan perundang-undangan yang berlaku, baik Undnag-Undang Republik Indonesia, maupun peraturan internal dari institusi kedokteran gigi yang menyangkut pelaksanaan penelitian kesehatan. Mahasiswa juga perlu memberikan informasi dari hasil penelitian kepada subjek penelitian yang bersangkutan karna hal tersebut adalah salah satu hak dari masyarakat sebagaisubjek penelitian.

d. Untuk masyarakat sebagai subjek penelitian, perlu lebih aktif dalam komunikasi sehingga masyarakat lebih memahami hak-hak dalam posisinya sebagai subjek penelitian, sehingga masyarakat tidak merasa ragu ketika dilibatkan sebagai subjek penelitian. 


\section{DAFTAR PUSTAKA}

\section{Buku}

Adi, Rianto. (2005), Metodologi Penelitian Sosial dan Hukum, Jakarta : Granit.

Budiarto, Eko (2003). Metodologi Penelitian Kedokteran: Sebuah Pengantar. Jakarta:EGC.

Bungin, M.Burhan. (2017). metodologi Penelitian Kuantitatif. Komunikasi, Ekonomi, dan Kebijakan Publik Serta Ilmu-ilmu sosial Lainnya. Jakarta:PT Fajar Interpratama Mandiri.

Fitrah, Muh,. dan Luthfiyah. (2017). Metodologi Penelitian: Penelitian Kualitatif, Tindakan Kelas \& Studi Kasus.Sukabumi: CVJejak

Hanafiah, M.Jusuf dan Amir, Amri. Ed 4. (2008). Etika kedokteran \& hukum kesehatan. Jakarta: EGC.

Klitzman, Robert L. (2015), The Ethics Police?: The struggle to make research safe, Oxford University Press.

Santoso, Moch. Istiadjid Edi. (2011), Buku Ajar Etik Penelitian Kesehatan. Malang :Universitas Brawijaya Pess.

Smith, Trevor. (2001). Ethics in Medical Research: A Handbook of Good Practice. Newyork: Cambridge University Press.

Soekamto, Soerjono. (1986), Pengantar Penelitian Hukum, Jakarta : Universitas Indonesia Press.

Susanto, Djoko. (2017), Begini Mencetak Dokter Profesional, Surabaya: Airlangga University Press.

Jurnal

Artikel. Beberapa Kasus Pelanggaran/Malpraktek Penelitian\&Publikasi. https://docplayer.info/45677851-Beberapa-kasus-pelanggaran-malpraktek-penelitianpublikasi-a-kasus-1-david-reimer-lahir-di-kanada-pada-22-agustus-ia-adalah-seoranganak.html. Diakses 6 Agustus 2019. Jam 12.28.

Kemenkes Republik Indonesia "Pedoman dan Standar Etik Penelitian dan Pengembangan Kesehatan Nasional", https://ners.unair.ac.id/site/images/KEPK/08.\%20Pedoman\%20KEPPKN-20017.doc. Diakses pada tanggal 07/04/2019 jam 10:49wib

Pappworth, M H. (1990). Human Guinea pigs - a history. BM Journal Volume 301. Diakses melalui:

https://www.google.com/url?sa=t\&rct=j\&q=\&esrc=s\&source=web\&cd=1\&cad=rja\&uac $\mathrm{t}=8 \&$ ved=2ahUKEwjKhejr27HIAhVc_XMBHTXJDdMQFjAAegQIABAB\&url=https\%3A\%2F \%2Fwww.ncbi.nlm.nih.gov\%2Fpmc\%2Farticles\%2FPMC1679859\%2F\&usg=AOvVaw12gsq zabX9XhfBv8FQUvAF

Yustina, Endang Wahyati. (2018). "Withdrawing life supports theraphy in human rights perspective". Journal of Advances in Heath and Medical Science. Vol: 4(2):32-42. Diakses melalui : https://tafpublications.com/gip_content/paper/Jahms-4.2.1.pdf 
Yustina, Endang Wahyati. 2014. "Hak atas Informasi Publik dan Hak atas Rahasia Medis: Problem Hak Asasi Manusia dalam pelayanan Kesehatan". Padjajaran Jurnal Ilmu Hukum, Volume 1(2). Hlm:264-266 . http://jurnal.unpad.ac.id/pjih/article/view/7077/3279

\section{Peraturan Perundang- Undangan}

Undang-Undang Dasar Negara Republik Indonesia Tahun 1945. Diakses dari: http://www.dpr.go.id/jdih/uu1945

Kitab Undang-Undang Hukum Perdata. Diakses melalui

http://www.bpkp.go.id/public/upload/unit/maluku/files/Viewer.js/Peraturan/Hukum/KUHP-

Perdata-Bagian-1.pdf

Undang-Undang No. 29 Tahun 2004 Tentang Praktik Kedokteran. Diakses melalui:

https://peraturan.bpk.go.id/Home/Details/40752/uu-no-29-tahun-2004

Undang-Undang No. 36 Tahun 2009 Tentang Kesehatan. Diakses melalui:

https://peraturan.bpk.go.id/Home/Details/38778/uu-no-36-tahun-2009

Undang-Undang No 20 Tahun 2013 Tentang Pendidikan Kedokteran. Diakses melalui:

https://peraturan.bpk.go.id/Home/Details/38895/uu-no-20-tahun-2013

Peraturan Pemerintah Nomor 39 Tahun 1995 Tentang Penelitian dan Pengembangan Kesehatan. Diakses melalui:

https://peraturan.bpk.go.id/Home/Details/57094/pp-no-39-tahun-1995

Peraturan Pemerintah Republik Indonesia Nomor Tahun 2015 Tentang Rumah Sakit Pendidikan. Diakses melalui: https://peraturan.bpk.go.id/Home/Details/5672

Peraturan Menteri Kesehatan Republik Indonesia Nomor 7 Tahun 2016 Tentang Komisi Etik Penelitian dan Pengembangan Kesehatan Nasional. Diakses melalui:

http://hukor.kemkes.go.id/uploads/produk_hukum/PMK_No._7_ttg_Komisi_Etik_Penelitian _dan_Pengembangan_.pdf

Peraturan Menteri Riset, Teknologi, dan Pendidikan Tinggi Republik Indonesia Nomor 18 Tahun 2018 Tentang Standar Nasional Pendidikan Kedokteran. Diakses melalui:

https://jdih.ristekdikti.go.id/view-file/?id=de304a88-6cd5-476b-af90-59e6cd3d5067

Peraturan Kepala Lembaga IImu Pengetahuan Indonesia Nomor 06/E/2013 Tentang Kode Etika Peneliti. Diakses melalui:

http://pusbindiklat.lipi.go.id/wp-content/uploads/Perka-LIPI-No.-8-Tahun-2013-tentang-

Pedoman-Klirens-Etik-Penelitian-dan-Publikasi-Ilmiah-Copy.pdf 